\title{
Editorial
}

\section{High-Strength Low-Alloy Steels}

\author{
Ricardo Branco ${ }^{1, *}$ and Filippo Berto ${ }^{2}$ \\ 1 CEMMPRE, Department of Mechanical Engineering, University of Coimbra, 3030-78 Coimbra, Portugal \\ 2 Department of Mechanical and Industrial Engineering, Norwegian University of Science and Technology, \\ 7491 Trondheim, Norway; filippo.berto@ntnu.no \\ * Correspondence: ricardo.branco@dem.uc.pt
}

Citation: Branco, R.; Berto, F. High-Strength Low-Alloy Steels. Metals 2021, 11, 1000. https:// doi.org/10.3390/met11071000

Received: 8 June 2021

Accepted: 16 June 2021

Published: 23 June 2021

Publisher's Note: MDPI stays neutral with regard to jurisdictional claims in published maps and institutional affiliations.

\section{Introduction}

Modern industry, driven by the recent environmental policies, faces an urgent need for the production of lighter and more environmentally friendly components. High-strength low-alloy steels are key materials in this challenging scenario because they provide a balanced combination of properties, such as strength, toughness, formability, weldability, and corrosion resistance. These features make them ideal for a myriad of engineering applications which experience complex loading conditions and aggressive media, such as aeronautical and automotive components, railway parts, offshore structures, oil and gas pipelines, power transmission towers, construction machinery, among others. The goal of this Special Issue is to foster the dissemination of the latest research devoted to highstrength low-alloy (HSLA) steels from different perspectives.

\section{Contributions}

The understanding of the microstructure features and their dependence on the mechanical behaviour is of essential importance for the development of safe and durable components as well as to extend the scope of application of the high-strength low-alloy steels. This may justify the intense research conducted on the triangular relationship between the microstructure, the processing techniques, and the final mechanical properties. Solis-Bravo et al. [1] addressed the relationship between the precipitate morphology and dissolution on grain coarsening behaviour in microalloyed linepipe steels with different contents of titanium and niobium. The effect of the hot deformation and the cooling path on the phase transformation kinetics of precipitation-strengthened automotive steels with different contents of titanium and niobium was also examined by Grajcar et al. [2]. Xie et al. [3] studied the effect of nanometre-sized interphase-precipitated carbides on the improvement of monotonic tensile strength in fire resistant hot-rolled steel at room and high temperature. The effect of dissolution and precipitation of different carbides at high temperature on the microstructure of a low-alloy chromium-containing heat-resistant steel was also analysed by Li et al. [4].

Regarding the processing techniques and the evaluation of mechanical properties, different research lines were followed. Guo et al. [5] evaluated the casting process conditions on the mechanical properties of hot-rolled steel and studied the billet quality by developing and optimisation method. Khosravani et al. [6] tackled the microstructural changes that occur during the processing of dual-phase steels by using multiresolution spherical indentation stress-strain tests. Dzioba et al. [7] focused on the effect of temperature on fracture toughness and tensile strength properties of low-carbon high-strength steel. Iob et al. [8] examined the anisotropic mechanical behaviour of high-strength low-alloyed steel based on the micro-void and ductile fracture. The mechanical properties of high-strength low-carbon steels, with different contents of molybdenum and niobium, processed thermomechanically and subjected to direct quench were investigated by Hannula et al. [9]. A numerical study to deal with the cutting problem of ultra-thin steel sheets made of cold rolled steel was developed by Kaczmarczyk et al. [10]. 
Another active area of research has been welding engineering. It has not been focused on the optimisation of welding techniques but also on the evaluation of microstructure features and mechanical properties. Mičian et al. [11] studied the influence of the cooling rates on mechanical properties of the heat-affected zone, obtained by metal active gas welding, in S960ML high-strength structural steels. The effect of the welding heat input on the heat-affected zone of S960QL high-strength structural steels was also investigated numerically by Gáspár [12]. Moravec et al. [13] examined the effect of grain growth kinetics on the changes of the mechanical properties of the heat-affected zone in a S700MC finegrained high-strength steel. The fracture toughness response under static and dynamic loading in the same material was examined by Schmidová et al. [14].

The presence of abrupt geometrical changes in conjunction with complex cyclic loads make most mechanical components prone to fatigue failure. This means that engineering design must be able to account for the loading history, the geometrical effects, the environmental effects, and the processing variables, among others. Jiménez-Peña et al. [15] compared the fatigue response of high-strength low-alloy plates with holes manufactured by five processes, namely punching, drilling, waterjet-cut, plasma, and laser-cut. Guo et al. [16] evaluated the variability in the mechanical properties of pipeline steel associated with the centreline segregation in continuously cast slab to meet the requirements of strain-based design. Ślęzak [17] studied the fatigue crack initiation and fatigue crack growth in welded joints made of S960QL high-strength low-alloy steel subjected to straincontrolled conditions. Harun et al. [18] analysed the effect of the localized wall thinning on low-cycle fatigue resistance of elbows, with artificially introduced defects, made of C70600 steel from full-scale tests.

The fatigue design under multiaxial loading is another challenging topic. The development of multiaxial fatigue assessment models as well as the identification of adequate fatigue damage quantifiers remain important objectives for the scientific community. However, it is a very complex task because, in general, multiaxial fatigue response is associated with a huge number of variables. Pawliczek and Rozumek [19] presented an algorithm based on the Palmgren-Miner linear damage rule for calculating the fatigue life in S355J0 steel specimens subjected to multiaxial non-zero mean stress histories. Cruces et al. [20] compared the predictive capabilities of different critical plane-based models for hollow specimens made of S355-J2G3 steel subjected to in-phase and out-of-phase axial-torsional loading in the low-cycle and the high-cycle fatigue regimes.

Within the high-strength low-alloy steels, the third generation plays an important role. The macroscopic mechanical response of this new generation can be further improved by a better understanding of the failure mechanisms on the microstructural level under different service conditions. Shakerifard et al. [21] conducted a comprehensive microstructural characterization of a multiphase low-silicon bainitic steel using a scanning electron microscope (SEM) equipped with an electron backscatter diffraction detector. Concerning metallic structures operating in soils and natural waters, corrosion under the effect of a stray current is among the most hazardous types of damage. Rybkina et al. [22] addressed the effect of sign-alternating cycling polarisation on the localised corrosion of pipelines made of X70 steel subjected to various $\mathrm{pH}$-neutral solutions.

Acknowledgments: This research is sponsored by FEDER funds through the program COMPETEPrograma Operacional Factores de Competitividade — and by national funds through FCT—Fundação para a Ciência e a Tecnologia—under the project UIDB/00285/2020.

Conflicts of Interest: The authors declare no conflict of interest.

\section{References}

1. Solis-Bravo, G.; Merwin, M.; Garcia, C.I. Impact of Precipitate Morphology on the Dissolution and Grain-Coarsening Behavior of a Ti-Nb Microalloyed Linepipe Steel. Metals 2020, 10, 89. [CrossRef]

2. Grajcar, A.; Morawiec, M.; Zalecki, W. Austenite Decomposition and Precipitation Behavior of Plastically Deformed Low-Si Microalloyed Steel. Metals 2018, 8, 1028. [CrossRef] 
3. Xie, Z.; Song, Z.; Chen, K.; Jiang, M.; Tao, Y.; Wang, X.; Shang, C. Study of Nanometer-Sized Precipitation and Properties of Fire Resistant Hot-Rolled Steel. Metals 2019, 9, 1230. [CrossRef]

4. Li, Z.; Jia, P.; Liu, Y.; Qi, H. Carbide Precipitation, Dissolution, and Coarsening in G18CrMo2-6 Steel. Metals 2019, 9, 916. [CrossRef]

5. Guo, F.; Wang, X.; Wang, J.; Misra, R.D.K.; Shang, C. The Significance of Central Segregation of Continuously Cast Billet on Banded Microstructure and Mechanical Properties of Section Steel. Metals 2020, 10, 76. [CrossRef]

6. Khosravani, A.; Caliendo, C.M.; Kalidindi, S.R. New Insights into the Microstructural Changes During the Processing of Dual-Phase Steels from Multiresolution Spherical Indentation Stress-Strain Protocols. Metals 2020, 10, 18. [CrossRef]

7. Dzioba, I.; Pała, R. Strength and Fracture Toughness of Hardox-400 Steel. Metals 2019, 9, 508. [CrossRef]

8. Iob, F.; Cortese, L.; Di Schino, A.; Coppola, T. Influence of Mechanical Anisotropy on Micro-Voids and Ductile Fracture Onset and Evolution in High-Strength Low Alloyed Steels. Metals 2019, 9, 224. [CrossRef]

9. Hannula, J.; Porter, D.; Kaijalainen, A.; Somani, M.; Kömi, J. Mechanical Properties of Direct-Quenched Ultra-High-Strength Steel Alloyed with Molybdenum and Niobium. Metals 2019, 9, 350. [CrossRef]

10. Kaczmarczyk, J.; Kozłowska, A.; Grajcar, A.; Sławski, S. Modelling and Microstructural Aspects of Ultra-Thin Sheet Metal Bundle Cutting. Metals 2019, 9, 162. [CrossRef]

11. Mičian, M.; Harmaniak, D.; Nový, F.; Winczek, J.; Moravec, J.; Trško, L. Effect of the $\mathrm{t}_{8 / 5}$ Cooling Time on the Properties of S960MC Steel in the HAZ of Welded Joints Evaluated by Thermal Physical Simulation. Metals 2020, 10, 229. [CrossRef]

12. Gáspár, M. Effect of Welding Heat Input on Simulated HAZ Areas in S960QL High Strength Steel. Metals 2019, 9, 1226. [CrossRef]

13. Moravec, J.; Novakova, I.; Sobotka, J.; Neumann, H. Determination of Grain Growth Kinetics and Assessment of Welding Effect on Properties of S700MC Steel in the HAZ of Welded Joints. Metals 2019, 9, 707. [CrossRef]

14. Schmidová, E.; Bozkurt, F.; Culek, B.; Kumar, S.; Kuchariková, L.; Uhríčik, M. Influence of Welding on Dynamic Fracture Toughness of Strenx 700MC Steel. Metals 2019, 9, 494. [CrossRef]

15. Jiménez-Peña, C.; Goulas, C.; Preußner, J.; Debruyne, D. Failure Mechanisms of Mechanically and Thermally Produced Holes in High-Strength Low-Alloy Steel Plates Subjected to Fatigue Loading. Metals 2020, 10, 318. [CrossRef]

16. Guo, F.; Liu, W.; Wang, X.; Misra, R.D.K.; Shang, C. Controlling Variability in Mechanical Properties of Plates by Reducing Centerline Segregation to Meet Strain-Based Design of Pipeline Steel. Metals 2019, 9, 749. [CrossRef]

17. Ślęzak, T. Fatigue Examination of HSLA Steel with Yield Strength of $960 \mathrm{MPa}$ and Its Welded Joints under Strain Mode. Metals 2020, 10, 228. [CrossRef]

18. Harun, M.F.; Mohammad, R.; Kotousov, A. Low Cycle Fatigue Behavior of Elbows with Local Wall Thinning. Metals 2020, 10, 260. [CrossRef]

19. Pawliczek, R.; Rozumek, D. The Effect of Mean Load for S355J0 Steel with Increased Strength. Metals 2020, 10, 209. [CrossRef]

20. Cruces, A.S.; Lopez-Crespo, P.; Moreno, B.; Antunes, F.V. Multiaxial Fatigue Life Prediction on S355 Structural and Offshore Steel Using the SKS Critical Plane Model. Metals 2018, 8, 1060. [CrossRef]

21. Shakerifard, B.; Galan Lopez, J.; Kestens, L.A.I. A New Electron Backscatter Diffraction-Based Method to Study the Role of Crystallographic Orientation in Ductile Damage Initiation. Metals 2020, 10, 113. [CrossRef]

22. Rybkina, A.; Gladkikh, N.; Marshakov, A.; Petrunin, M.; Nazarov, A. Effect of Sign-Alternating Cyclic Polarisation and Hydrogen Uptake on the Localised Corrosion of X70 Pipeline Steel in Near-Neutral Solutions. Metals 2020, 10, 245. [CrossRef] 